Siservations on the art of oltaining zoter by boring the earth; with some animadversions on the Ealitor's notice of a jatent for certain improvements iherein obtained, by Lei Disbrow and Juhn L. Sullivan, in . $1 u$ gust last.

By Jom L. Sorrivar, Givil Engines:

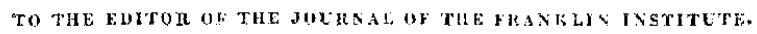

Sik,-Since the progress of goology in our cuntry has discovered to us that our cilies of the middle states have, in the stratified rock beneath them, springs of the purest water, accessible by the art of boring with that peculiar set of instruments which has been invented by Mr. Levi Disbrow, and to which our joint patent has given system, and extended usefulness, I felt much regret to see, in your number for March last, that the Journal had done itself, and us, and the subject, injustiet. It seems fo me that a discovery so interesting to the convenience, econoiny, and health of our cities, and an art so singularly fortunate for them, merited at least that the specification should have been correctly described. I think, indeed, that a provision of a nature so singularly advantageous, as tending to relieve us from one of the disadvantages incident to our decp alluvial soil, deservel at the hands of philosophical inquiry, a more thorough and candil investigation. It was indeed $\mathrm{my}$ intention, at my earliest leisure, to have asked your acceptance of an article on the subject. This I shall now do with all possible brevity, offering the apology to your Philadelphia readers, of my persuasion that, notwitlistanding the proud achievment of the Fair Mount water works, the public will crentually believe that the rock springs, the waters of the natural aqueduct of the primitive rock descending from the Alleghenies, is preferable for the table; and that an abundant supply of it will prove to be a powerful auxiliary to the temperance societics, as it will supply a beverage requiring no foreign flavouring to counteract its unpleasant taste.

It gave me some surprise that the writer of the article should have sought to inake an unfavourable impression of the practical usefulness of the essays made by the inventor of this art. If from the circumstance of obtaining overflowing borings in the first four instances he was led to hope for equal success in all other places, it was surely excusable, even if no satisfactory theory could be advanced to account for it. And to insinuate that his operations had been in some indefinite number of cases abandoned, or " suspended," after considerable expense, when but one instance of it could be named, (that of Alexandria,) while 100 instances of success have been even published, was surely less liberal than night have been expected of the Frankin Journal.

The Alexandria corporation obtained good water at ninety fect, where a bed of clay succeder to coarse sand; but, desirous of an

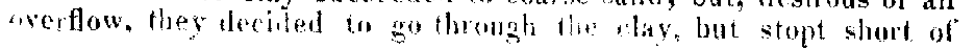


it at 400 feet. It was unphilosophical to stop, as in 500 feet they would have reached the shelving rock, in all probability, and have had water enough for the whole city.

That there was reason to expect an overflow, is proved not only by the instances of it, but by the rising of the water so high in the tubes as to be higher than the contiguous ground. Thus in a boring on the hipliest point of the island of New Fork, at the botanic garden, the water stanls at least eighty feet above tide, and twenty leet above adjacent grounds. So also in borin ar at the corner of Bleecher street and Broalvay, the ground leing fify feet above tole, the rock fortyeight feet under surface, the boring too feet therein, the rise was nine. teen feet above the surface of the rock. If, instead of this soil, the rock had been the surface, this perforation would have produced a copious overflow. The water actually rises higher than the ground of hall the cily.

The well known geology of the midlle states suggests the obvious explanation. 'The primitive stratitied rock of the Allegheny mountains slopes down, underlaying the secondary rocks, and appears to gain an upwarl slope on approaching the sea coast, as seen at the falls of our rivers. But in the latitude of New York, and New Fongland, it continues to rise till it has formed the Green Moutains. There are two ranges through Massachusetts; the more eastern is granite, the east side of the west and intermediate valley in Berkshire, is gneiss, the third general formation described by Professor Eaton in his geological survey; and these strata appear to be remarkably pro. ductive of water. It pours out the sources of the Housatonic; and as it ranges southward between the Croton and the Broux, gives forth large springs that form their head waters in ponds, and continuing south is depressel under Harlaem river, and again rises to form the principal rough elevations of this island; it is then depressed 100 feet under the city and the Hudson, and, gradually rising as it underlays New Jersey, is found forty feet only under the soil in the Northern Liberties of Philadelphia, and is above ground at haltimore.

Every boring into this rock has afforded this pure water, and in many instances even the approach to its surface bas brought up a large supply. Mr. Disbrow has just finished in Baltimore one of this kind for the corporation in the made land, and another for an individual in the rock. There are in New York four in rock, and ten in earth, and the fact is demonstrable that the whole city can be better supplied in this way than in any other, even at half the expense of introducing the nearest stream. And a similar calculation might be made for the northern and southern liberties of Philadelphia, were they not already supplied.

The principle of our joint patent whereby any one boring is made to yield as much water as a steam engine of small size can pump; (that is, enough for 2000 families with a ten horse power, high enough to flow rapidly from a reservoir to the hauses, is founded as the specification expresses, in availing oursel ves of the hydrostatic pressure, or velocity of discharge through orifices. Suppose the water stands 100 foet deep in the tube, and a pump is placed therein nearly as deep, and 
the power reduces this head of water to eighty-one feet, the velocity of the water entering will be that due to dhis head, which is seventy-two feet a second. Now make any reasonable supposition that the water may not come as fast, yet if it comes fast enough to krep the power at work, a larger quantity will be raised than 2000 families require.

At one boring here, a six horse cngine gave, experimentally, last summer, ninety gallons a minute. Another gives constantly with one horse power, twenty gallons a minute, (all the establishment wants, ) and might raise 80 gallons a minute with a ten horse engine. In this instance the rock boring is 130 leet, the earth 74 feet, the rise of water to within liftecen feet of the surface of the ground, thus stanling 189 feet deep.

To take oft the stress which deep and strong pumping occasions to the lower liting box, we have devised the expedient which you, by the article alluded to, have, it secms, not perfectly comprehenderl, in imagining that our pump box (as we have contrived it,) had valves opening downwards. I should really have thought, before so representing it, you might have been so kind as to have asked me, by letter, how this could possibly be.

The simple matter of fact is, that a scries of boxes on the same rod, each having its chamber, divide the column, say into ten parts, each liftiner ten feet of it; thus, though all have the bottom fixed valve in common, they constitute a succession of pumps one above the other, and might thus lift to any considerable requisite elevation, and cause the water to follow and rise in proportion to the depth of the draft, and the power employel. The mode of forming the boxes which we prefer is to cause an enlargement of the rod, in the shape of a bulb, to fit the bottom of the box, and let this play on the rod hall an inch, to permit the water to pass through it, as this makes a very strong box; but they may also be tixed on the rod, and have fly valves above. The essence of the improvement is the series, dividing the weight of the columb.

You thus perceive that the geological formation of these subterraneous aqueducts present our fortunate cities, seated as lliey are on deep sands, or clay, with pure water in abundance, beyond the influcnce of seasons, and the wants of population; that art has devised the means of reaching them, and that principles of science have made them available; presenting to men of capital and philanthropy, opportunities of benevolent and profitable insestment in forming water companies.

And permit me here, briefly to mention the plan of financial operation we, as patentees of these improvements, propose-

1. For mechanic and professional services, the usual compensation.

2. For benefit, as patentees, one-half the surplus revenue, beyond interest-but at the termination of the privilege, our emolument ceases, and then the city authorities take our place, and are for ever entitled to this revenue, devoted to the support of charitable socie ties and institutions. 
There are few considerable cities where this plan will not justify the forming of a water company.

With great respect and esteem, yodrs, \&c. J so. L. Suldisis.

Norv Fork, 14 May, 1833.

\section{Remarks by the Editor.}

Notwithstanding the grave charges of our friend sullivan, "sour withers are unwrung." No willing, or known, "injustice" has been lone in the article in our March number p. 176. If we thought it worth while to bandy charges of this description, we could find enough in the foregoing communication upon which to found the procedures we shall not do this however, because it wonld be a very profitless cmployment, and because we believe that Mr. Sullivan has mistaken our notice in several points which a more calm examination of them has ere now, probably, corrected, and which most of our readcrs will be able to correct, by comparing the said notica with $\mathrm{Mr}$. Sullivan's letter. We gave, in the words of the patentees, their own account of their joint improvement, thus enabling our readers to judge for themselves. Upon reviewing the article in question we find nothing to retract, or to modify, or we would most cheerfully do it; we make some claim to candour, but none to infallibility, and can assure Messrs. Disbrow and Sullivan, that no one residing at the distance of two hundred miles from New York, will more sincerely rejoice in the perfect success of their undertaking than will the editor of this Journal.

Although we have determined not to make a long article of our present remarks, we will take a brief notice of some of the points al. luded to by Mr. Sullivan. When speaking of the instances in which Mr. Disbrow had, after much labour, suspended his operations, we alluded, exclusively, to his former expectations of being able, every where, to obtain overflowing wells; and we are certain that $\mathrm{Mr}$. S. will not say that Alexandria is the only place which offers an example of such fialure, but that he will, on the contrary, confess that success to this extent has been comparatively rare. There are but few places where water cannot be found by digging, and, of course, by boring. We have, upon some very elevated ground in the city of Washington, wells with an abundant supply of water, at the depth of sixteen feet, and if Messrs. Disbrow and Sullivan had sent down the auger at the same spot, they would undoubtedly have succeeded at the same depth.

Where Mr. S. finds that we have spoken of, or alluded to, valves "opening downwards," we know not; one thing is certain, that such a thought never cntered into our heads, and we presume, therefore, that it did not escape from the goose quill at the ends of our fingers; we had no inducement, therefore, "to have asked by letter how this could possibly be." "We certainly, if time admitted of it, should grladly correspond with Mr. Sullivan, as we might thus have obtained 